\title{
Reduction of gastrointestinal protein loss by elemental diet in Crohn's disease of the small bowel
}

\author{
R F A LOGAN*, J GILLON, C FERRINGTON, AND ANNE FERGUSON \\ From the Gastro-Intestinal Unit and Department of Medical Physics, Western General Hospital and \\ University of Edinburgh, Edinburgh
}

SUMMARY Seven patients with hypoalbuminaemia and extensive jejunoileal Crohn's disease were treated with an elemental diet for 28 to 56 days. Over this time there was an increase in total plasma proteins from mean of 49.1 to $59.0 \mathrm{~g} / 1$ and a mean rise in serum albumin from 20.7 to $30.0 \mathrm{~g} / 1$ $(P<0.05)$. In addition, there was a $47 \%$ mean reduction in plasma protein loss into the gastrointestinal tract and a rise in blood lymphocyte count in all patients $(P<0.05)$. These results suggests that, as well as providing nutritional support, elemental diets reduce protein and lymphocyte loss from the diseased intestine.

Elemental diets, which are both liquid and chemically defined, have been available for the past decade and have been used in a variety of clinical situations, usually when a minimal faecal residue is desirable. ${ }^{1}$ In the managment of Crohn's disease they have an accepted but limited role, particularly in the presence of extensive disease and fistulae, where they can maintain nutrition and reduce fistula output without resort to intravenous feeding. In this gastrointestinal unit, we have used elemental diets in the treatment of Crohn's disease for some years, and, like others, have anecdotal evidence of benefit. However, published experience of this treatment in patients with Crohn's disease is scant, and the variability of the disease renders convincing evidence of benefit difficult to obtain..$^{2-6}$ We have therefore assessed the effect of an elemental diet in a group of patients with hypoproteinaemia due to small bowel Crohn's disease. We have measured the effect of this treatment by studying gastrointestinal protein loss, as a reflection of inflammatory activity, in addition to conventional biochemical and haematological indices.

\section{Methods}

Patients (Table 1)

Seven patients with extensive jejunoileal Crohn's disease were given an elemental diet. No patient had

\footnotetext{
*Address for correspondence and requests for reprints: Dr Richard F A Logan, Gastro-Intestinal Unit, Western General Hospital, Edinburgh EH4 2XU.
}

Received for publication 2 December 1980 rectal or colonic Crohn's disease as determined by double-contrast barium enema, sigmoidoscopy, and rectal biopsy. All seven patients had been underweight with hypoproteinaemia and hypoalbuminaemia for several months before starting the diet. Patients 1, 5, and 7 had had previous jejunoileal resections of $135 \mathrm{~cm}, 60 \mathrm{~cm}$, and $40 \mathrm{~cm}$ respectively.

\section{INDICATIONS FOR DIET}

All seven were admitted to the study because, over several months, they had gradually deteriorated with increasing lack of energy, poor appetite, and weight loss or oedema formation. In patients 5 and 7 weight loss was associated with marked abdominal pain and clinical evidence of subacute small bowel obstruction and elemental diet was given for an agreed period before surgery.

\section{OTHER TREATMENT}

In the months before the study and during the study period there were no changes made in any other treatments except for the addition of folic acid for patient 2. No patient was receiving steriods; four patients had been on salazopyrin for at least one year.

\section{PROTOCOL}

In the week before starting the diet, the patients were weighed, venous blood was taken on two occasions five to seven days apart and gastrointestinal protein loss was assessed as described below. The patients were then started on a diet of high nitrogen Vivonex (Eaton Laboratories, Woking, UK) building up to six packets per day $(1800 \mathrm{Kcal} /$ day or $7.536 \mathrm{MJ} /$ day 383 
Table 1 Clinical details

\begin{tabular}{|c|c|c|c|c|c|c|c|c|}
\hline Patient & $\operatorname{Sex}$ & $\begin{array}{l}\text { Age } \\
(y r)\end{array}$ & $\begin{array}{l}\text { Extent of disease* } \\
(\mathrm{cm})\end{array}$ & $\begin{array}{l}\text { Ideal } \uparrow \\
\text { weight } \\
(\%)\end{array}$ & $\begin{array}{l}\text { Predominant } \ddagger \\
\text { symptoms }\end{array}$ & $\begin{array}{l}\text { Duration } \\
(y r)\end{array}$ & Other treatment & $\begin{array}{l}\text { Days on } \\
\text { diet }\end{array}$ \\
\hline $\begin{array}{l}1 \\
2 \\
3\end{array}$ & $\begin{array}{l}\mathbf{F} \\
\mathbf{F} \\
\mathbf{F}\end{array}$ & $\begin{array}{l}42 \\
30 \\
35\end{array}$ & $\begin{array}{l}\text { Ba FT- +125 } \\
\text { LAP-130 } \\
\text { LAP- }+70\end{array}$ & $\begin{array}{l}77 \\
96 \\
90\end{array}$ & $\begin{array}{l}\text { O,LoE,D } \\
\text { O,LoE,WL } \\
\text { O,LoE,AP+ }\end{array}$ & $\begin{array}{r}18 \\
3 \\
12\end{array}$ & $\begin{array}{l}\text { Iron, folic acid, vit } \mathbf{B}_{12} \\
- \\
\text { Salazopyrin, azathioprine, vit } \\
\mathbf{B}_{12} \text {, iron, folic acid }\end{array}$ & $\begin{array}{l}38 \\
28 \\
47\end{array}$ \\
\hline $\begin{array}{l}4 \\
5 \\
6 \\
7\end{array}$ & $\begin{array}{l}\mathbf{F} \\
\mathbf{M} \\
\mathbf{M} \\
\mathbf{M}\end{array}$ & $\begin{array}{l}31 \\
54 \\
34 \\
40\end{array}$ & $\begin{array}{l}\text { Ba FT }-100 \\
\text { LAP-5 } \mathrm{cm} \times 5 \\
\text { Ba FT }-30 \mathrm{~cm} \times 2 \\
\text { LAP-70 }\end{array}$ & $\begin{array}{l}91 \\
85 \\
79 \\
84\end{array}$ & $\begin{array}{l}\text { O,LoE,AP+ } \\
\text { WL,AP+ + } \\
\text { WL,LoE,AP+ } \\
\text { WL,AP+ + }\end{array}$ & $\begin{array}{r}10 \\
5 \\
1 \\
8\end{array}$ & $\begin{array}{l}\text { Salazopyrin, folic acid, vit } \mathbf{B}_{12} \\
\text { Salazopyrin, iron } \\
\overline{\text { Salazopyrin, vit } \mathbf{B}_{12}}\end{array}$ & $\begin{array}{l}56 \\
45 \\
34 \\
32\end{array}$ \\
\hline
\end{tabular}

- Extent on barium follow through (Ba FT) or at laparotomy (LAP).

+ Calculated according to standard weight for height charts, adapted from DB, Jeliffe, The Assessment of the Nutritional Status of the Community, WHO Geneva, 1966.

$\ddagger$ : oedema. LoE:lack of energy. WL:weight loss. D:diarrhoea. AP:abdominal pain marked ++ , moderate + .

and $80 \mathrm{~g}$ /day of amino acids). Clear soups, tea and coffee without milk, and some fruit flavoured juices were also allowed and the patients discharged home when fully established on the diet. In the last week of treatment patients were readmitted and measurements repeated.

\section{VENOUS BLOOD MEASUREMENTS}

Total plasma proteins, albumin, immunoglobulins, iron, and iron binding capacity were measured in the clinical chemistry department, Western General Hospital. Serum albumin was estimated using an electrophoretic method and serum immunoglobulins were measured on an autoanalyser with an immune precipitation technique. Plasma iron was measured using Ferro Zine ${ }^{7}$ and plasma iron binding capacity was measured with a resin binding technique.

Absolute lymphocyte counts were calculated from the total white blood cell count as determined on a Coulter counter and a differential white cell count performed by one observer who was unaware of the clinical details.
The values given below are the mean of the duplicate specimens taken for these venous blood measurements, before and at the end of treatment.

\section{GASTROINTESTINAL PROTEIN LOSS \\ MEASUREMENT ${ }^{8} 9$}

After an intravenous injection of approximately $100 \mu \mathrm{Ci}^{51} \mathrm{CrCl}_{3}, 10 \mathrm{ml}$ heparinised blood was taken after two hours and then at 24 hourly intervals for five to seven days. All stools passed during this period were collected individually. All patients were ambulant and continent, obviating errors due to contamination of stool with urine.

The ${ }^{51} \mathrm{CrCl}_{3}$ labels plasma protein generally and any loss of protein across the bowel wall will be detected as radioactivity excreted in stool, the chromium isotope not being significantly reabsorbed. Normally, less than $1 \%$ of the administered activity is detected in the stool collection. By analysis of the plasma activity related to corresponding stool activity, gastrointestinal protein loss can be expressed as the plasma equivalent lost or cleared into

Table 2 Results of investigations

\begin{tabular}{|c|c|c|c|c|}
\hline Mean values & Laboratory reference range & Before diet & After diet & Significance* \\
\hline $\begin{array}{l}\text { Plasma protein }(\mathrm{g} / \mathrm{l}) \\
\text { Serum albumin }(\mathrm{g} / \mathrm{l}) \\
\text { Serum IgG }(\mathrm{IU} / \mathrm{ml}) \\
\text { Plasma iron }(\mu \mathrm{mol} / \mathrm{l}) \dagger \\
\text { Plasma iron binding capacity } \\
\quad(\mu \mathrm{mol} / \mathrm{l})\end{array}$ & $\begin{array}{lr}60- & 80 \\
35- & 50 \\
90- & 170 \\
14- & 22 \\
50- & 64\end{array}$ & $\begin{array}{c}49 \cdot 1 \\
20 \cdot 7 \\
121 \\
6 \\
40\end{array}$ & $\begin{array}{c}59 \cdot 0 \\
30 \cdot 0 \\
141 \\
9 \cdot 6 \\
56 \cdot 3\end{array}$ & $\begin{array}{l}\mathrm{P}<0.05 \\
\mathrm{P}<0.05 \\
\mathrm{NS} \\
\mathrm{NS} \\
\mathrm{P}<0.05\end{array}$ \\
\hline Haemoglobin $(\mathrm{g} / \mathrm{dl}) \dagger$ & $\begin{array}{r}\text { F } 11 \cdot 5-16 \cdot 5 \\
\text { M } 13 \cdot 5-18 \cdot 0\end{array}$ & $\begin{array}{l}11 \cdot 4 \\
11 \cdot 7\end{array}$ & $\begin{array}{l}12 \cdot 9 \\
11 \cdot 9\end{array}$ & $\begin{array}{l}\text { NS } \\
\text { NS }\end{array}$ \\
\hline $\begin{array}{l}\text { Absolute lymphocyte count } \\
\left(10^{6} / 1\right) \\
\text { Gastrointestinal protein loss } \\
\text { as equivalent plasma }\end{array}$ & $1500-3500$ & 1177 & 1579 & $P<0.05$ \\
\hline $\begin{array}{l}\text { clearance (ml/day) } \\
\text { Body weight expressed as } \\
\text { percentage of ideal weight } \\
\text { for height }\end{array}$ & $<25 \mathrm{ml} /$ day & 190 & $99 \cdot 5$ & $P<0.05$ \\
\hline
\end{tabular}

\footnotetext{
* Using Wilcoxon's signed rank sum test.
}

+ Six patients only. 


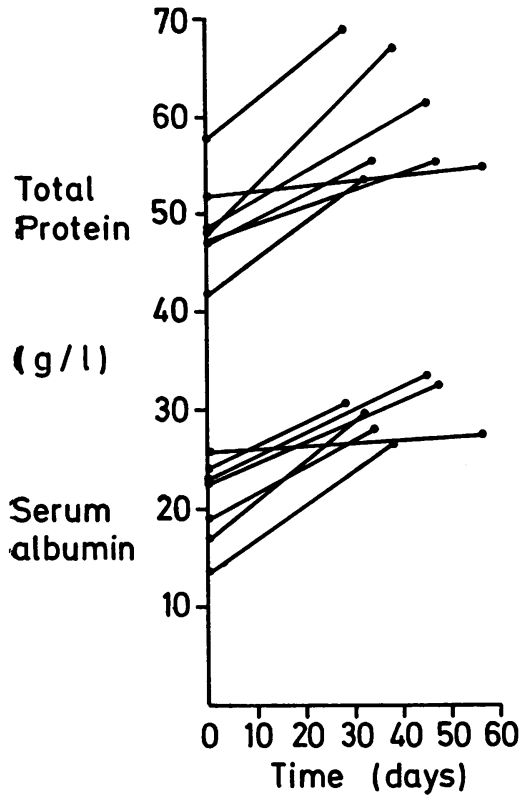

Fig. 1 Total plasma protein and serum albumin before and after elemental diet.

the bowel daily. To minimise error due to varying transit times, gastrointestinal protein loss was derived from the integral of the plasma radioactivity curve and the total stool radioactivity and expressed as equivalent plasma clearance (normal $<25 \mathrm{ml} /$ day).$^{10}$ Gastrointestinal protein loss assessed by this technique shows a close correlation $(r=0.98)$ with fractional catabolic rates of albumin, measured using ${ }^{125}$ I labelled albumin. ${ }^{11}$

\section{Results}

\section{LABORATORY INVESTIGATIONS}

All seven patients showed a rise in total plasma protein, serum albumin, plasma iron binding capacity, and peripheral blood lymphocyte count (Table 2, Figs. 1, 2, 3). Each patient also showed a reduction in gastointestinal protein loss (Fig. 4) with a mean reduction value of $47.5 \%$.

Although there was some correlation between apparent extent of diseased small bowel, as assessed by surgeon or radiologist, and initial gastrointestinal protein loss $(r=0.86)$ the reduction in protein loss followed no obvious pattern and did not appear to relate to the duration of the diet $(r=-0 \cdot 26)$. There was no correlation between duration of elemental diet and biochemical improvement nor between initial gastrointestinal protein loss and degree of biochemical abnormality.

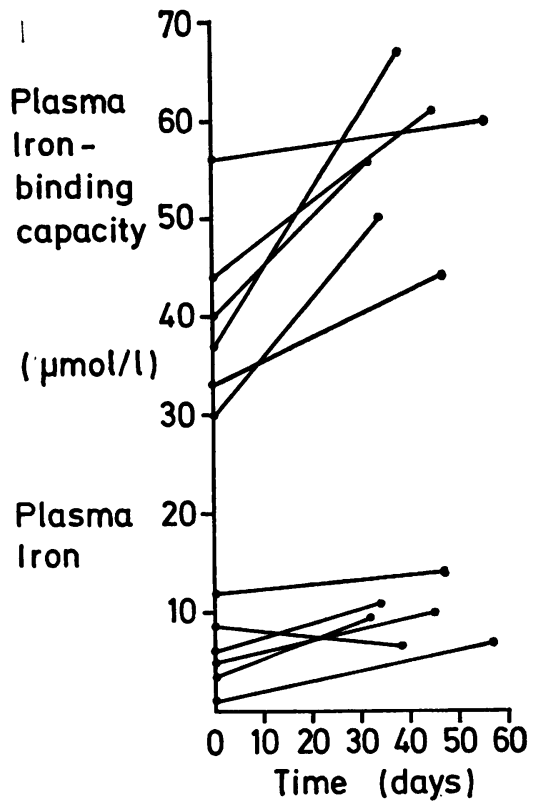

Fig. 2 Plasma iron and iron binding capacity before and after elemental diet.

During the pretreatment assessment patient 2 was found to have a macrocytic anaemia with a haemoglobin of $8.8 \mathrm{~g} / \mathrm{l}$, plasma lactate dehydrogenase of $2198 \mathrm{IU} / 1$ (normal 72-395 IU/1), and serum folate of $0.9 \mathrm{mg} / 1$ (normal $>2.0 \mathrm{mg} / \mathrm{l}$ ). After one month of folic acid the haemoglobin had risen to $11.8 \mathrm{~g} / \mathrm{l}$; the results for haemoglobin, plasma iron, and iron binding capacity have therefore been omitted from Table 2.

\section{CLINICAL EFFECTS}

Formal assessment of clinical response was not attempted in view of the recognised placebo effect of dietary therapy. However, despite the unpalatability of the diet, all seven patients remarked on increased energy and sense of wellbeing within a week of its introduction. Patients 5 and 7 , both of whom had had previous small bowel resections, were given the diet before surgery for symptoms of subacute small bowel obstruction; while on the diet both patients became asymptomatic. Four patients had ill-defined abdominal pains, mild colic, and borborygmi which were much reduced while taking the elemental diet.

In the group as a whole, there was no significant weight change, although in four patients, ankle oedema disappeared during the period of diet.

MAINTENANCE OF IMPROVEMENT

So far it has not been possible to determine how long 
this improvement can be maintained. Two of the seven patients (patients 5 and 7) had laparotomies on completing the period of elemental diet and areas of jejunal stricture and active Crohn's disease were resected. One of the other five patients (patient 6) developed increasing abdominal pain and has subsequently had a good response to steroid therapy.

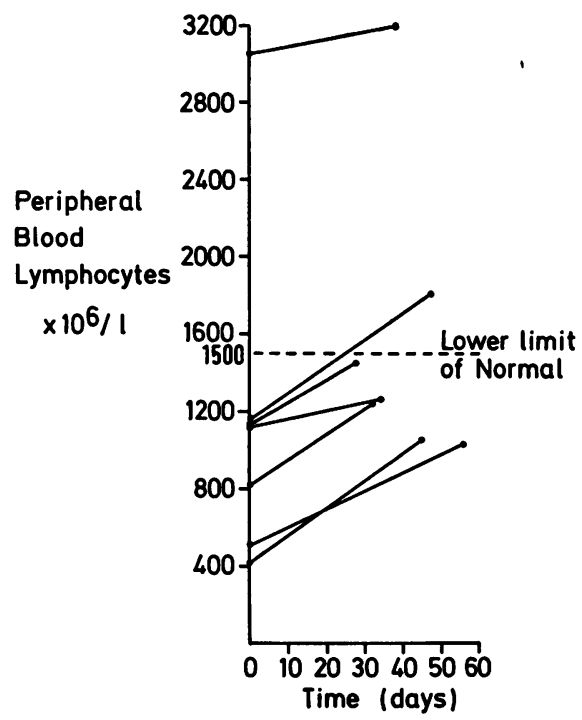

Fig. 3 Absolute lymphocyte count before and after elemental diet.

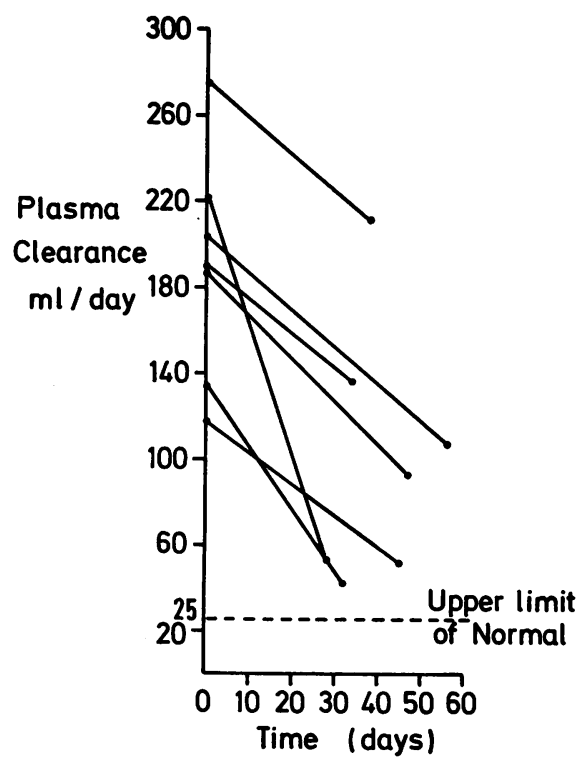

Fig. 4 Gastrointestinal protein loss before and after elemental diet.
Of the four remaining patients, all women, improvement in wellbeing appeared to last for several months and post-treatment levels of plasma protein, albumin and iron binding capacity were maintained for three, four, six, and seven months before declining towards pretreatment levels. Patients 3 and 4 have since developed increasing abdominal pain and have had respectively a $100 \mathrm{~cm}$ small bowel resection and steroid therapy. Patients 1 and 2 had a gradual recurrence of symptoms of anorexia, lack of energy, weight-loss, and oedema. At 11 and 7 months respectively they were given an elemental diet again and had reductions of $26 \%$ and $54 \%$ in their measured gastrointestinal protein losses along with similar increases in plasma protein, albumin, and iron binding capacity.

\section{Discussion}

Formal studies of elemental diets in man are constrained by the unpalatability of the diets. Administration using nasogastric intubation or even gastrostomy or jejunostomy can overcome this difficulty but these measures have obvious disadvantages. The fact that our patients tolerated their elemental diets as outpatients testifies, we believe, to the increased wellbeing they experienced while on the diet. Studies of oral and parenteral feeding in Crohn's disease are additionally complicated by the unpredictable and fluctuating nature of the disease and the lack of any ready measure of response. Indices such as the Crohn's disease activity index ${ }^{12}$ include food-related symptoms such as pain and diarrhoea, and may be improved by the mere withdrawal of normal food. Such an improvement is not evidence of a change in disease activity. When we are confronted with these problems it is understandable that reported experience of elemental diets in Crohn's disease is so limited, and mainly concerns their use in critically ill patients who have been receiving steroids as well as many other drugs. ${ }^{2-6}$ Clinical improvement in such patients may reflect correction of nutritional deficits rather than any change in the underlying disease. As yet no controlled studies have been reported. Our finding of a reduction in gastrointestinal protein loss after a period of elemental diet is contrary to that of Axelsson and Jarnum ${ }^{13}$ who found a significant reduction in protein loss in only one of four patients studied. However, in their patients an elemental diet was tried as a 'last resort' before surgery for ileocolonic Crohn's disease. Nevertheless eight out of 11 of their patients in an acute exacerbation of Crohn's disease went into clinical remission when an elemental diet was added to their therapy, which included steroids. ${ }^{6}$

Although elemental diets have been found to 
reverse chronic weight loss in Crohn's disease ${ }^{4}$, the absence of a significant weight gain in our patients is not surprising, for the maximum daily calorie intake was only 1800 calories and reduction in oedema could have masked small weight changes in four of the patients.

The correlation between gastrointestinal protein loss and length of affected bowel in Crohn's disease has been previously noted. ${ }^{14}$ The lack of correlation of duration of diet with reduction of protein loss and improvement in biochemical indices possibly reflects the several factors, including anorexia and malabsorption, which contribute to the malnutrition of Crohn's disease.

The importance of nutritional support in Crohn's disease is now accepted. The induction of a clinical remission in Crohn's patients, with resumption of skeletal growth in adolescents, during total parenteral nutrition is well established ${ }^{1516}$ and has usually been assumed to be the consequence of improved nutritional support, often due to a true hyperalimentation. Increases in blood proteins such as we have demonstrated are also usually assumed to reflect improved nutrition in these patients. Although this is likely to be partly true, some of the benefits of parenteral nutrition may be the consequence of a degree of 'bowel rest' ${ }^{17}$ Our finding of reduced gastrointestinal protein loss after elemental diet lends support to this concept by demonstrating that dietary manipulation can have a direct effect on small bowel involved by Crohn's disease. The increases in circulating lymphocyte counts reflects, we believe, reduced gastrointestinal loss of lymphocytes and so is an additional, indirect, measure of the reduction in inflammatory exudate with elemental diet therapy.

We have not attempted to establish which of the properties of elemental diets have produced this effect. Several properties of the diets could be relevant, including those of being low in dietary fat, virtually free of dietary antigens, as well as their requirement for minimal digestion before absorption. If only one of these properties has produced the benefit in this group of seven patients with jejuoileal Crohn's disease, the possibility arises that dietary manipulation, less radical than the use of an elemental chemically defined diet, could provide similar benefit in Crohn's disease. In any event, both for elemental diet therapy and total parenteral nutrition, clinical benefit in inflammatory bowel disease should not be assumed to be solely the consequence of increased availability of nutrients to a catabolic, undernourished patient.

We wish to thank Dr W Sircus for allowing us to study patients under his care, the nursing staff of the Gastro-Intestinal Unit who so skilfully administered the elemental diets, and the Departments of Clinical Chemistry and Haematology, Western General Hospital, for their assistance.

\section{References}

${ }^{1}$ Russell RI. Elemental diets. Gut 1975; 16: 68-79.

${ }^{2}$ Stephens RV, Randall MT. Use of a concentrated balanced liquid elemental diet for nutritional management of catabolic states. Ann Surg 1969; 170: 642-67.

${ }^{3}$ Voitk AJ, Echave V, Feller JM, Brown RA, Gund EN. Experience with elemental diet in the treatment of inflammatory bowel disease, in this primary therapy. Arch Surg 1973; 107: 329-33.

${ }^{4}$ Rocchio MA, Chung-Ja Mo Cha, Haas KF, Randall HT. Use of chemically defined diets in the management of patients with acute inflammatory bowel disease. $\mathrm{Am}$ J Surg 1974; 127: 469-75.

${ }^{5}$ Goode A, Hawkins T, Fegetter IGW, Johnston IDA. Use of an elemental diet for long-term nutritional support in Crohn's disease. Lancet 1976; 1: 122-4.

${ }^{6}$ Axelsson CK, Jarnum S. Assessment of the therapeutic value of an elemental diet in chronic inflammatory bowel disease. Scand J Gastroenterol 1977; 12: 89-95. ${ }^{7}$ Stookey LL. Ferro Zine-a new spectrophotometric reagent for iron. Anal Chem 1970; 42: 779-81.

${ }^{8}$ Rubini ME, Sheehy TW. Exudative enteropathy, a comparative study of $\mathrm{Cr}^{51} \mathrm{Cl}$ and $\mathrm{I}^{131} \mathrm{PVP}$. J Lab Clin Med 1961; 58: 892-901.

${ }^{\circ}$ Waldmann TA. Protein-losing enteropathy and kinetic studies of plasma protein metabolism. Semin Nucl Med 1972; 2: 251-64.

${ }^{10}$ Van Tongeren JMM. Reichert WS. The demonstration of protein losing gastroenteropathy: The quantitative estimation of gastrointestinal protein loss using ${ }^{51} \mathrm{Cr}$ labelled plasma proteins. Clin Chim Acta 1966; 14: 42.

"Waldmann TA, Woehner RD, Strober W. The role of the gastrointestinal tract in plasma protein metabolism. Am J Med 1969; 46: 275.

${ }^{12}$ Best WR, Becktel JM, Singleton JW, Kern F. Development of a Crohn's Disease Activity Index. Gastroenterology 1976; 70: 439-44.

${ }^{13}$ Axelsson CK, Jarnum S. Influence of an elemental diet on protein exudation in chronic inflammatory bowel disease. Digestion 1977; 16: 77-86.

${ }^{14}$ Beeken WL, Baseh MJ, Sylvester DL. Intestinal protein loss in Crohn's disease. Gastroenterology 1971; 62: 207.

${ }^{15}$ Kelts DG, Grand RJ, Shen G, Watkins JB, Werlin SL. Boehme C. Nutritional basis of growth failure in children and adolescents with Crohn's disease. Gastroenterology 1979; 76: 720-7.

${ }^{16}$ Layden T, Rosenberg J, Nemchausky B, Elson C, Rosenberg IH. Reversal of growth arrest in adolescents with Crohn's disease after parental alimentation. Gastroenterology 1976; 70: 1017-21.

${ }^{17}$ Rosenberg IH. Nutritional support in inflammatory bowel disease. Gastroeneterology 1979; 77: 393-5. 